\title{
SINFONIA NARRATIVA: A METAFICÇÃO EM $O$ TRIUNFO DA MORTE, DE AUGUSTO ABELAIRA
}

\author{
Natália Ubirajara Silva*
}

\begin{abstract}
RESUMO: O presente trabalho objetiva analisar o romance O triunfo da Morte, do autor português Augusto Abelaira, à luz dos conceitos de multiplicidade e metaficção. Valendo-nos da visão de Italo Calvino, que considera o romance moderno uma enciclopédia, mostramos como esse "romancesinfonia" abelairiano compendia não apenas questionamentos e temáticas, mas também a função da literatura e os próprios processos de criação do autor.
\end{abstract}

PALAVRAS-CHAVE: Romance português contemporâneo - Multiplicidade - Metaficção

RESÚMEN: El presente trabajo tiene como objetivo analisar la novela $\mathrm{O}$ triunfo da Morte, del autor portugués Augusto Abelaira, seguiendo los conceptos de multiplicidad y metaficción. A partir de la visión de Italo Calvino, que considera la novela moderna una enciclopedia, mostramos como esa "novelasinfonia" abelairiana compendia no solo questionamentos y temáticas, pero también la función de la literatura y los própios procesos de creación del autor.

PALABRAS-CLAVE: Novela portuguesa contemporânea-Multiplicidad-Metaficción

Augusto Abelaira (1926-2003) pode ser apresentado como um ilustre desconhecido. Ilustre, por ser um dos maiores escritores portugueses da segunda metade do século XX, com uma extensa obra e tendo sido premiado diversas vezes; desconhecido, pela ainda tímida atenção que tem recebido dos estudiosos de literatura portuguesa no Brasil ${ }^{1}$. Autor de doze romances, um livro de contos e três peças, sua primeira publicação foi o romance $A$ Cidade das Flores (1959), mas sua obra mais aclamada é Bolor (1968). O presente ensaio abordará o sétimo romance de Abelaira, $O$ triunfo da Morte, publicado em 1981.

Em $O$ triunfo da Morte, a diversidade de caminhos na leitura é tal, que não podemos deixar de encará-lo como um romance enciclopédico, segundo o pensamento de Calvino: "O que toma forma nos grandes romances do século XX é a idéia de uma enciclopédia aberta", baseada na "confluência e [n]o entrechoque de uma multiplicidade de métodos interpretativos, maneiras de pensar, estilos de expressão" (2005, p. 131), fazendo do romance uma "rede de conexões" (ibid., p. 121). A narrativa de Abelaira exemplifica muito bem essa "confluência e entrechoque" de métodos, pensamentos e estilos apontados por Calvino, pois nela podemos encontrar, por exemplo, questionamentos filosóficos, temática metaficcional, enredo (com direito a triângulo amoroso), etc. Remédios (1986, p. 214) considera essa obra um romance de pesquisa, não só pelo experimentalismo, mas também pela multiplicidade de temas e

\footnotetext{
* Mestranda em Literatura Portuguesa pelo Programa de Pós-Graduação em Letras da Universidade Federal do Rio Grande do Sul (UFRGS), natisil1@hotmail.com. Este trabalho foi desenvolvido com o auxílio do $\mathrm{CNPq}$ - Brasil.

${ }^{1}$ A maior parte dos estudos sobre o autor refere-se às obras do período anterior à Revolução dos Cravos (1974). As obras posteriores têm sido estudadas, mas ainda de maneira incipiente.
} 
pontos de vista. Para explicar essa multiplicidade, o narrador-protagonista de $O$ triunfo da Morte compara sua narrativa a uma sinfonia:

A quem, numa sinfonia, ouça apenas um belo tema delineado pelos violinos, talvez não interesse o fundo quase imperceptível e contraditório dos metais, das madeiras, da percussão. Mas revelarei agora esse fundo imperceptível que, contrapondo-se ao resto, transforma a Sinfonia Heróica numa complexa rede de temas cantáveis e de sons aparentemente inúteis. O tema essencial, aquele que melhor entra no ouvido, tenho-o vindo a esboçar, discretamente entregue aos violinos: o da morte dos meus amigos, o da minha responsabilidade, falsa ou verdadeira. Mas em surdina aí vai o que simultaneamente (como lamento não poder dá-lo simultaneamente!) as flautas murmuram num outro ritmo. Contribuindo para a harmonia do todo. (ABELAIRA, 1981, p. 9-10) ${ }^{2}$

Percebe-se, na citação acima, a definição da narrativa como uma complexa rede, constituída por diferentes níveis. Um deles é o que o narrador chamou de temas cantáveis, mais à superfície, entregues aos violinos e que melhor entram no ouvido (melhor compreensão). Há ainda o nível das flautas, dos chamados sons aparentemente inúteis que, em surdina, requerem a atenção do leitor não só para percebê-los, mas para compreender as contradições neles presentes. Esses dois níveis apontados pelo narrador remontam à análise de Tutikian (1977) acerca de Bolor. Segundo a autora, esse romance pode ser dividido em dois eixos: o progressivo, "nível do real objetivo", e o digressivo, que "leva a narrativa para direções imprevistas" (p. 16). A associação desses dois níveis, portanto, repete-se em $O$ triunfo da Morte.

Dentre os "temas cantáveis", destacamos o enredo, extremamente diluído - só se percebe uma "história" no sentido tradicional nos intervalos entre longas digressões. $O$ triunfo da Morte apresenta 110 capítulos, em que o narrador-protagonista relata a um interlocutor, de maneira a-linear, a descoberta de sua condição de Morte e, em conseqüência, integrante da Thanatus House (casa da Morte), espécie de sociedade secreta. $\mathrm{O}$ narrador reavalia sua existência à luz dessa descoberta, questionando sua culpa e responsabilidade nas mortes de amigos e conhecidos:

O acontecimento que sempre me ocorre, quase sempre me ocorre, quando me debruço sobre os tempos do meu primeiro ano do liceu é a morte do Carlos Manuel ou, se quiserem, as circunstâncias singulares da sua morte.

Havíamos combinado uma corrida. Quem chegaria primeiro à parede? Aí a metade do caminho (e ele ia à frente) caiu - queda infeliz, bateu com a cabeça numa pedra, chegou sem vida no hospital.

Nessa época impressionei-me com o desastre, embora não me sentisse responsável. Só alguns anos depois.

Certo dia, inesperadamente, recordei-me fora eu a convidá-lo. E uma campainha retiniu no meu espírito: se não o tenho desafiado... Um sentimento absurdo de culpabilidade? Eu, pecador, me confesso... (OTM, p. 1-2)

Desse modo, o narrador, nesse nível mais superficial, procura "fazer um balanço [...], pôr as ideias em ordem" (OTM, p. 62), analisando alguns episódios de seu passado. A gravidade que poderia advir de uma situação como essa é quebrada pelo modo como

\footnotetext{
${ }^{2}$ Ao longo de nosso trabalho, $O$ triunfo da Morte será referido como OTM, tomando por base a seguinte edição: ABELAIRA, Augusto. O triunfo da Morte. Lisboa: Sá da Costa, 1981.
} 
o narrador foi "eleito" como Morte. Seu ingresso na Thanatus House se dá por acidente: internado num hospital, o narrador ouve uma voz que revela o seu papel de Morte no mundo. Por ironia, o narrador havia trocado de quarto, sendo a intimação, na verdade, destinada ao paciente anterior, o dr. Eduardo Nunes. Abaixo segue a convocação do narrador, um episódio que beira o cômico:

\footnotetext{
"Deste as tuas provas, podemos confiar em ti..." Deus?, pensei, embora não pudesse acreditar que pertencesse a Deus uma voz tão desagradável. A voz continuou: "Seguimos-te desde o nascimento, augurámos-te um grande futuro... Provaste o teu valor [...] Lembras-te de quando brincavas com o Afonso?" Eu nunca brincara com nenhum Afonso. "Convidas-te-o a trepar a um monte de pedras, ele caiu e morreu. Mais tarde desafiaste o Rui para ir sozinho ao cemitério à meia-noite. A aposta de pregar um prego na sepultura, mas pregou-o na gabardine sem dar por isso e quando quis fugir sentiu-se preso e morreu de susto." Isto também era falso [...] Tudo, tudo falso, somente algumas histórias parecidas. Arquivos mal-organizados? A teleinformática que não chegara ainda ao céu?

Concluiu: "Agora passarás a ter consciência..." Consciência de quê? (OTM, p. 52-53)
}

Depois dessa descoberta, ao transitar entre a vida cotidiana e as idas à Thanatus House, o narrador enceta um caso amoroso com uma mulher-Morte, que só depois ele descobre ser Eduarda Navarro, esposa de seu sócio e melhor amigo, Eurico Nogueira. É apenas ao fim do romance que se percebe que todos eram Mortes, não só o narrador, como também a amante e Eurico. O final, ambíguo, dá a entender que a amante mata o narrador.

Após os 110 capítulos, Abelaira "brinca" com as estruturas formais, criando uma "Nota do responsável desta edição" tão ficcional quanto o resto da obra. Nessa nota, o suposto editor joga com as interpretações possíveis e diz tentar esclarecer pontos obscuros da narrativa. Suas várias opções interpretativas, no entanto, acabam por desnortear o leitor, ratificando a multiplicidade da obra: vários caminhos são apresentados, mas o leitor escolherá qual percorrer. Como o editor afirma, "compete aos leitores tirar conclusões" (OTM, p. 145). Mantendo o tom de indefinição e ambigüidade que permeia toda a narrativa, o editor se identifica apenas como E. N., iniciais que podem ser atribuídas a três personagens: Eduarda Navarro (amante), Eurico Nogueira (amigo traído) e Eduardo Nunes (o professor que deveria ser Morte em lugar do narrador). Vê-se, desse modo, que mesmo o nível mais superficial da narrativa é uma rede complexa, um quebra-cabeça de situações e personagens que o leitor precisa montar se quiser compreender o romance em toda a sua riqueza.

É necessário dizer, porém, que esses "temas cantáveis", de mais fácil compreensão, ocupam muito menos espaço na obra. O próprio fato de o narrador anunciar que há diversos níveis em sua "sinfonia" denuncia que o enredo, tradicionalmente mais importante, não é o principal foco de sua narrativa. Como assinala Remédios, "o narrador identifica referentes externos, ou seja, Paris, restaurante, Portugal [...], porém é nos referentes internos que centra sua narrativa" (REMÉDIOS, 1986, p. 215). Esses referentes internos, cerne da narrativa, são os já mencionados "sons aparentemente inúteis". Dentre eles, destacamos as digressões do narrador, lembrando uma afirmação de Laurence Sterne que podemos aplicar a $O$ triunfo da Morte: "as digressões são incontestavelmente a luz do sol, são a vida, são a alma da leitura; retiraias deste livro, por exemplo - e será melhor se tirardes o livro juntamente com elas" 
(STERNE apud CHALHUB, 2002, p. 78). Sterne é, inclusive, citado pelo narrador abelairiano:

Faço uma pausa, não vá a atenção dos meus cúmplices afrouxar [...] Acrescentarei somente, um pouco à maneira de Fielding e de Sterne: quem quiser pode abster-se de ler o próximo capítulo. Pode abster-se até de ler todos os capítulos - e isto não se atreveram a dizer nem o Fielding nem o Sterne. A minha nota original, o meu avanço sobre eles (OTM, p. 30)

O narrador, no trecho acima, revela que a força de sua narrativa se concentra nas digressões, reflexões, nos desvios, em detrimento do enredo, por mais interessante que ele seja. Poderíamos dizer, de maneira simplista, que tanto faz pular um ou dez capítulos na leitura, pois não se perdem acontecimentos e peripécias. Gomes (1993) percebe ser essa uma característica da ficção portuguesa da atualidade, constatando que "no romance português contemporâneo, o narrador mais do que contar tem o hábito de falar" (GOMES, 1993, p. 123). As digressões do narrador de O triunfo da Morte versam sobre os mais diversos tópicos: o fazer literário, a questão da morte encarada filosoficamente, a ironia perante o comportamento humano. A própria definição da sinfonia ao fundo como contraditória, conforme a citação que apresentamos anteriormente, revela que a multiplicidade é pretendida de maneira consciente pelo narrador; ele busca entrechocar e enredar diversos pontos de vista sobre os mais variados aspectos em uma mesma obra. É uma unidade obtida pela costura de temas diversos numa verdadeira rede, representando em si a "multiplicidade das relações, em ato e potencialidade", tecendo "em conjunto os diversos saberes e os diversos códigos numa visão pluralística e multifacetada do mundo", no dizer de Calvino (2005, p. 127).

Ainda quanto à multiplicidade, vale salientar que a leitura desse romancesinfonia é proveitosa qualquer que seja o nível "ouvido". Ele pode ser tomado como história de amor ("a sensação de abusar duplamente da confiança do Eurico: roubavalhe a mulher e ao mesmo tempo, e sem ele suspeitar, era seu confidente", OTM, p. 125); conversa despretensiosa ("Dizia eu há dez minutos? Prometi o quê? Já não me lembro bem, mas inventemos outra coisa", OTM, p. 16); trechos em folhas de rascunho ("tudo quanto escrevi até hoje não passa dum rascunho que mais tarde aperfeiçoarei”, OTM, p. 54); diálogo com a mulher amada ("Ouve... E se tiver escrito esta história a pensar em ti? Se todo o meu discurso apenas significa uma declaração de amor, o pedido para não me deixares?", OTM, p. 126); reflexão metaliterária ("De facto, para quem escrevo? Para mim, de modo a pôr em ordem as ideias? [...] Um público interessado na história romanesca da minha vida?", OTM, p. 35); discussão filosófica ("Com a Morte, não, ela pode decidir matar-te mesmo quando teu maquinismo funciona bem. A Morte introduz o sem sentido no mundo e isso não o suportas tu", OTM, p. 78); olhar irônico perante a sociedade ("E quanto às profissões [das Mortes]: 50\% militares, $18 \%$ médicos, $17 \%$ políticos, $3 \%$ ortopedistas, $2 \%$ escritores, $5 \%$ psicanalistas e $3 \%$ bispos", OTM, p. 122); reflexão sobre Portugal ("Gostaria de saber: entre os políticos portugueses, quantas Mortes haverá? Não me refiro a Salazar, esse não oferece dúvidas”, OTM, p. 97), dentre muitos outros aspectos. Essa diversidade comprova o caráter de enciclopédia romanesca da obra de Abelaira, coadunando-se à visão do "romance contemporâneo como enciclopédia, como método de conhecimento" (CALVINO, 2005, p. 121).

À luz dessa multiplicidade, discordamos, ainda que em termos, de Azevedo Filho (1987) quando afirma que a obra de Abelaira engana "o leitor ingênuo, que ficou preso ao nível das ações, sem penetrar no eixo paradigmático da linguagem” (p. 140), 
pois o caráter enciclopédico do romance garante uma leitura rica qualquer que seja o nível operado. Faz parte do jogo da leitura de $O$ triunfo da Morte aceitar sua multiplicidade de rumos na leitura, encarando-o como uma sinfonia em que as mais diversas sonoridades e instrumentos se reúnem. Não há desprezo em relação aos leitores que sabem operar apenas no nível dos "temas cantáveis", pois sem esse nível mais superficial não seria possível haver os "sons aparentemente inúteis" que compõem o fundo; os dois níveis, portanto, complementam-se e contribuem para a "harmonia do todo" (OTM, p. 10). Passaremos, agora, à análise de um dos aspectos de fundo dessa sinfonia, em surdina ao longo de toda a obra: a metaficção.

Metaficção pode ser explicada como a ficção que fala sobre a ficção, e se relaciona ao termo metalinguagem, função da linguagem conceituada por Roman Jakobson. A metalinguagem é assim definida pelo teórico: "Uma distinção foi feita [...] entre dois níveis de linguagem, a 'linguagem objeto', que fala de objetos, e a 'metalinguagem', que fala da linguagem" (JAKOBSON, 1969, p. 127). É o discurso, portanto, que se auto-referencia. Como resume Chalhub, "a função metalingüística [...] é linguagem 'falando' de linguagem, é música 'dizendo' sobre música, é literatura sobre literatura, é palavra da palavra, é teatro "fazendo teatro" (2002, p. 32). Poderíamos acrescentar: é ficção escrevendo-se na ficção, revelando seu processo de construção e seus mecanismos de funcionamento. Assim, a metaficção nada mais é do que uma ficção metalingüística. Chalhub também afirma ser a metalinguagem (na ficção, nas artes plásticas, etc.) um traço da modernidade, apresentando a Revolução Industrial como "fermento metalingüístico" (id., ibid., p. 47): é a partir dela que surgem as obras que se revelam como construção. Antes, a arte era vista como reprodução do mundo; com o surgimento da fotografia, essa função de reprodução passa a ser questionada. Para que serve a arte, se a máquina também pode reproduzir o mundo? Surgem, então, as obras que refletem sobre si mesmas, buscando encontrar a especificidade da arte, a sua função estética. A construção metaficcional, portanto, é uma das características do romance moderno. Tutikian ratifica esse ponto de vista, postulando que

\begin{abstract}
o romance moderno se identifica por ser o não-romance. Uma forma resultante da própria desagregação do modelo tradicional, quando o gênero é criticamente refletido - propiciando, inclusive, o aparecimento do texto discutindo o texto, a palavra e a função da literatura - no intuito de querer atingir mais do que a descrição de situações ou caracteres, ou a simples pintura dos costumes de uma época ou sociedade. (1977, p. 5)
\end{abstract}

No romance português contemporâneo, essa auto-reflexão em busca de especificidade, num processo de auto-descoberta, intensificou-se. Na literatura posterior à Revolução dos Cravos (1974), o romance se liberta da "tirania da fábula" (GOMES, 1993, p. 120), não se fixando mais no enredo, na "história", mas na construção da obra, num movimento de "viragem da ficção, da direção referencial do relato, para a do metaromance" (SANTILLI, 1994, p. 31). Os autores operam um desmantelamento da narrativa, mostrando-nos parte por parte o seu processo de criação e discutindo o papel da literatura. No conjunto da produção de Abelaira, a metaficção pode ser verificada até mesmo nas suas primeiras obras - A Cidade das Flores (1959), Os desertores (1960) e As boas intenções (1963) - embora com enfoque diferenciado do que se vê posteriormente. Nesses romances, além do repúdio ao salazarismo e à imobilidade portuguesa (cf. TUTIKIAN, 1977), percebe-se a discussão do papel que a literatura e o escritor deveriam assumir em meio a um regime totalitário. Já em Bolor (1968) e nas 
produções pós-1974 (como O triunfo da Morte, de 1981, e Deste modo ou daquele, de 1990), a metalinguagem se intensifica. O foco, porém, não é mais o papel da palavra num Estado repressor, mas o questionamento acerca do fazer literário (seus processos, sua construção). O experimentalismo, marca de seus romances, acentua-se, e a discussão metaliterária toma forma na própria maneira de compor o texto. A tomada do romance como sinfonia em $O$ triunfo da Morte, por exemplo, é atitude metaficcional pois, ao problematizar a sua estrutura, a obra disseca a si mesma, desvelando seus recursos e elementos formais.

Cremos que o fato de essas obras serem posteriores à Revolução dos Cravos possibilitou que novos questionamentos - como o metaficcional - viessem à tona de maneira mais intensa; isso não só na obra de Abelaira, mas na ficção portuguesa de modo geral. Num tempo de mudança, não só o país se transforma: a literatura também acaba por reformular-se. Antes subjugada por um regime autoritário, defronta-se com uma nova conjuntura: a palavra, enfim, está em liberdade. Segundo Júdice (1997),

surgem, na década de 80 , os primeiros sinais de uma digestão mais 'tranquila' da vida democrática, de que o primeiro sinal é o ressurgimento do romance [...] fátuo período de renovação temática e estilística. (p. 93)

O período contemporâneo é, na visão do autor, época de "reconstrução e de reformulação" (ibid., p. 102) da ficção portuguesa. Assim se justifica o recrudescimento da temática metaficcional no romance português: busca de novos rumos após anos de censura, silenciamento. Vimos que no romance de Abelaira não há mais um único objetivo e/ou estilo, e sim múltiplos; dentre eles, como afirma Duarte (1984), há espaço para o desvelamento das mazelas sociais, tônica que vigorava nos anos de ditadura, mas não como temática principal. A denúncia social elaborada no período salazarista cede lugar a uma ficção que, assim como o país, precisa constituir-se novamente. É por isso que ela se auto-referencia, questionando-se e procurando redefinir o seu papel num sistema novo, num processo de "recomposição interior" (JÚDICE, 1977, p. 97) .

A multiplicidade, ainda seguindo o conceito de Calvino, faz-se presente também na temática metaficcional em $O$ triunfo da Morte. Abelaira, por meio de seu narrador, realiza uma espécie de inventário dos mais diversos processos de criação literária e dos diferentes papéis de autor, obra e leitor. Em nossa leitura, acreditamos que o narrador opta por uma concepção específica (a qual veremos em seguida), mas em nenhum momento se invalidam os outros modos do fazer literário problematizados no romance. Como o narrador deixa claro, "tanto faz dizer isto como aquilo, tudo parece certo" (OTM, p. 16). É a concretização daquela "confluência e entrechoque" de pensamentos de que fala Calvino. Veremos, agora, alguns dos aspectos metaficcionais da obra.

O narrador de $O$ triunfo da Morte, já nos primeiros capítulos, mostra sua visão acerca do que seja a criação literária: "Mas escrever... [...] Um processo de me inserir na sociedade, de me relacionar com os outros. O meio mais sedutor, não o único - poderia dedicar-me ao póquer ou à política" (OTM, p. 2-3). Consideramos esse trecho uma das chaves de leitura da obra. Para o narrador, há equivalência entre escrita, pôquer e política. Podemos embasar essa relação em dois aspectos: todos os três requerem o manejo da arte de fingir e pretendem, por meio desse fingimento, enganar outrem. Vale lembrar que a palavra ficção deriva de fingere, que significa, em latim, fingir, modelar (cf. MOISÉS, 1992, p. 229), comprovando essa característica da escrita afirmada pelo narrador de Abelaira. Em seguida a essa equivalência, o narrador afirma que, com sua obra, busca "criar uma expectativa - a arte, portanto. O jogo." (OTM, p. 4). Vemos, 
assim, que a arte/literatura é encarada como jogo, atestando a aproximação entre pôquer e escrita mencionada anteriormente. Tanto na arte como no jogo - e também na política - é preciso saber usar máscaras, blefar. Porém, é preciso recordar que esse fingimento será vão se não houver parceiros a serem enganados.

Fazer literatura como pôquer pode ser assim descrito: "Dispor de trunfos, mas administrá-los sabiamente, adiando o momento de os mostrar, fazer bluff. Conseguir parceiros, conseguir cúmplices para o jogo" (OTM, p. 4). Isso significa que pôquer e escrita requerem planejamento, avanços e recuos "ensaiados". A arte é jogo: calculada, fruto de raciocínio e estratégia, resultado de burilamento, trabalho, construção, concebida "em termos arquitetônicos" (CORTÁZAR, 1998, p. 64). Isso nos remete à famosa "Filosofia da Composição", de Edgar Allan Poe, em que a criação literária deve seguir a precisão de um problema matemático. Essa concepção se coaduna à de Chalhub, que vê a função poética como "um trabalho, e não uma inspiração" (2002, p. 19), contrapondo-se à escrita como transposição da imaginação tal qual ela é, em estado natural, sem aprimoramentos. O narrador refuta a criação como improviso e/ou inspiração momentânea (a que pretendia Alberto Caeiro, por exemplo), embora chegue a dizer, em alguns momentos, que sua criação não é trabalhada ou arquitetada: "[...] falo do que me vem à memória consoante me vem à memória" (OTM, p. 41). Apesar dessas palavras atestando despretensão e improviso, percebe-se que sua escrita é calculada em todos os aspectos. Até mesmo a desordem é estratégica:

Desprovido, infelizmente, de boa memória, as coisas vão-me surgindo ao acaso. Mas muitas vezes, quase sempre, trata-se de uma desordem voluntária [...] sirvo-me da desordem [...] isto para manter o interesse, evitar a desistência dos leitores (OTM, p. 45-46)

Assim, aquilo que lhe surge na memória não é colocado no papel sem raciocínio prévio, sem ser relevante para a construção do todo: "[...] minha vida é feita de muitas coisas desligadas desta história. Que poderia contar-se outra história baseada na minha vida. Que esta narrativa representa uma escolha. Talvez arbitrária. Talvez nem sequer a mais interessante" (OTM, p. 21). A criação literária é, pois, resultado de seleção, uma opção determinada por parte do escritor. Fruto de cálculo, portanto.

Dessa forma, a própria complexidade da narrativa é evidência de que a alegada simplicidade é, na verdade um blefe. Os blefes, como já vimos, constituem o pôquer e, por sua vez, a escrita: escrever é "dispor de trunfos [...], fazer bluff" (OTM, p. 4). Ao constituir o processo de criação, o blefe tem a função de obrigar o leitor a ser cúmplice, a agir sobre as cartas do "baralho narrativo", organizando-as, selecionando o que "serve" ou não, trabalhando sobre o texto. Como exemplo de blefe, temos as palavras do narrador acerca das suas motivações ao escrever. Pode-se dizer que a cada capítulo há uma nova concepção sobre os porquês do fazer literário. Em uma das suas muitas explicações, o narrador afirma escrever para ter status, seguir as tendências; a escrita seria um meio de inserção na vida social. Num outro momento, o narrador afirma escrever por amor à arte ("Sim, o fascínio da arte, pela arte aceito todos os sacrifícios", OTM, p. 5). Há ainda a visão do fazer literário como preenchimento do tempo, uma espécie de fuga do mundo ao redor, uma distração qualquer. $\mathrm{O}$ escritor é aquele que cria nas horas vagas, despretensiosamente. No trecho abaixo, o narrador chega a negar todos os pontos de vista mencionados anteriormente: 
Talvez possa dizer: as últimas páginas escrevi-as por uma única razão. Para o tempo passar mais depressa. Falando francamente, aguardo um telefonema sem esperança [...] E enquanto o tempo marcava passo e nenhum livro conseguia prender-me a atenção, puxei da caneta. Não a arte, não para me dirigir aos outros e nem sequer a ela, a ti, não a busca de cúmplices. Apenas para apressar o tempo, para o esquecer enquanto vou esperando. Apenas. (OTM, p. 4-5)

Ao expor essas opiniões contraditórias, o narrador está lançando suas "cartas", cabendo ao leitor, parceiro de jogo, descobrir o que é blefe ou não. Mais uma vez se revela a multiplicidade da narrativa abelairiana. Devido a ela, o narrador se dá o direito da contradição, realizando esse jogo de vaivém, pois seu intuito é justamente o de compendiar e expor as diferentes formas de se pensar sobre literatura. Cada modo de pensar é uma das "cartas na mesa".

Além de partir de cálculo, como vimos, a obra como jogo deve ser sempre executada em função de um parceiro: "Conseguir parceiros, conseguir cúmplices para o jogo" (OTM, p. 4). Tal qual o jogador de pôquer, o escritor não pode "jogar" sozinho; o leitor pode ser virtual, mas se faz presente:

Falemos portanto do dr. Nunes. Mas primeiro fumarei um cigarro. Não queres também fumar um cigarro? Pergunta absurda, limito-me a inventar um interlocutor, um cúmplice inexistente - mas poderia eu pôr as minhas ideias em ordem sem ele, mesmo inexistente? (OTM, p. 117)

Os leitores são os parceiros, que devem ser conquistados e enganados pelos blefes do narrador, mas sempre numa relação de cooperação e interdependência. Pôquer e escrita não são, portanto, atos solitários: cúmplices - palavra usada pelo narrador recorrentemente - são necessários, devendo participar ativamente da "partida". No caso de $O$ triunfo da Morte, essa cumplicidade do leitor se dá em dois níveis: mais superficialmente, enquanto conhecedores da personalidade secreta (Morte) do narrador; mais ao fundo, enquanto co-autores, operando sobre a narrativa. Como aponta Gomes,

a transformação do romance em espécie de puzzle alterará fundamentalmente a relação entre autor-leitor. Este, em vez de se comportar como mero observador, obriga-se a se tornar um co-partícipe, uma espécie de co-autor. (1993, p. 120)

Tomada como jogo, a escrita passa a ser encarada, pelo narrador, como "um acto solidário, um prazer que vive da relação com os outros" (OTM, p. 3), resgatando o leitor da passividade a que muitas vezes é relegado e alçando-o à condição de co-responsável pelo ato da criação: "o público não é mais passivo, pode ser incorporado, ativamente, como colaborador/leitor dentro da linguagem da obra" (CHALHUB, 2002, p. 43). Essa interdependência entre os parceiros da escrita faz com que o diálogo entre narrador e leitor não se dê apenas na estrutura da obra, mas se materialize: o autor imagina que o leitor é a sua amante (a mulher de Eurico) e que ela está a sua frente, ouvindo a narrativa:

Espera... Deixa-me imaginar-te mulher... Ouve, deixa-me supor: além de mulher, a mulher por quem me apaixonei. Que em silêncio ouves as minhas palavras. E embora eu escreva neste momento, embora neste momento não te veja, esse momento deixou agora de ser este, já não é o mesmo, mas 
outro, e já não escrevo, mas falo - e tu, ausente, tornaste-te presente, escutas-me... Verdade? (OTM, p. 117)

O público, portanto, funde-se com a figura da amante, personagem imaginada e materializada. De receptores, passamos a agentes, personagens da obra que lemos. O fato de o leitor ser vinculado à figura da amante não é fortuito. Equiparar leitor e mulher amada significa revelar o quanto a cumplicidade autor-leitor é profunda e essencial; nós, leitores e parceiros no jogo da escrita, somos tão íntimos do narrador quanto dois amantes o são. O narrador, na ânsia de agradar a amada, está, na verdade, buscando satisfazer o seu leitor:

Falo para ti, escrevi para ti e eis então uma descoberta importante. Subitamente, penso... Tu és a unidade procurada e só porque estás agora aí, porque já estavas no meu pensamento ao escrever estas páginas, porque permaneceste sempre a mesma pessoa, a mesma cúmplice, o mesmo corpo desde que comecei a falar, desde que comecei a escrever... Eu que procuro imitar-te, fazer-me à tua semelhança, ser uno e não apenas fragmentos descontínuos, responder aos teus desejos... Tu aí a ouvir-me, a ligar todos esses fragmentos numa unidade, tu que me dás a identidade procurada... Entendes? [...] ao falar-te sinto a minha unidade, sinto-me finalmente eu. (OTM, p. 136)

É o leitor quem une os fragmentos da narrativa num todo de sentido. Sem ele, a obra se torna vazia. Para o narrador, portanto, o fazer literário não se esgota em si mesmo, não é mera expressão de sentimentos do criador. O objetivo é chegar até o seu parceiro, atingir um fim. O narrador não está desabafando, mas falando diretamente a um interlocutor e contando com a sua interação.

A equivalência entre leitor e amante também é interessante se considerarmos o conjunto da obra de Abelaira, em que o diálogo amoroso e o casamento são freqüentemente enfocados. Nas suas primeiras obras, a tônica era o desgaste, a corrosão que o tempo exerce nos relacionamentos. No livro de contos Quatro Paredes Nuas (1972), porém, já se vislumbra uma nova abordagem do relacionamento amoroso, em que a cumplicidade entre os parceiros aflora. Nessa obra, quatro dos seis contos abordam o diálogo entre homem e mulher, mas distanciando-se da corrosão sem esperanças que se via em $A$ cidade das flores e Bolor. Em $O$ triunfo da Morte, Abelaira se vale de uma temática recorrente de sua produção para refletir sobre a literatura. A relação amorosa - envolvendo cumplicidade, intimidade, interdependência, jogos de dito e não-dito, desejos reprimidos, negação da própria vontade em prol do parceiro, busca da felicidade e prazer do outro, tentativa de adivinhar os desejos do amado pode ser equiparada à relação entre autor e leitor.

Considerando a afirmação de Chalhub de que o romance metaficcional "acaba por re-fazer, criticamente, a tradição narrativa: questionar o 'romanesco', isto é, o imaginário do texto" (2002, p. 70), vemos que, ao fundir leitor (parceiro no jogo da escrita) e mulher amada, o narrador nos propõe uma nova visão não só da obra abelairiana como um todo, bem como da tradição romanesca portuguesa. Em $O$ triunfo da Morte, Abelaira repensa a literatura após décadas de aprisionamento da linguagem pela censura ditatorial. Segundo Duarte (1984), há um questionamento latente dos padrões neo-realistas, como o caráter documental e de denúncia social da obra literária. O narrador neo-realista, de postura autoritária, não visava à participação de seu interlocutor, mas sim à sua doutrinação. O papel do leitor restringia-se, de modo geral, à 
recepção, a ser um espectador. No romance de Abelaira, por sua vez, o narrador deixa de ser o dono da verdade, tratando seu leitor como cúmplice, parceiro e amante, dando a ele o poder de agir sobre a palavra. Daí advém o caráter dialógico do texto: o narrador sempre se dirige a um interlocutor, seja ele virtual, o público posterior a uma eventual publicação ou a mulher amada. Qualquer que seja o interlocutor visado, o narrador busca orientar-se conforme as necessidades e anseios desse parceiro, deixando que este determine o que é blefe ou não, e vá preenchendo as lacunas da narrativa. Nesse sentido, nota-se a evolução da narrativa de Abelaira: do romance de narrador (ou "de autor", segundo Tutikian, 1977) para o romance do leitor, em que este não é mero receptor, mas um igual, "peça essencial da obra" (ZILBERMAN, 1989, p. 15). Na condição de cúmplice no fazer literário, o leitor "suja as mãos" tanto quanto o autor ao manipular o texto. Não há mais um receptor, mas um co-autor.

Para Duarte (1984), o trecho final do romance indica a supremacia do leitor, subvertendo toda a estética neo-realista: após 110 capítulos conduzidos exclusivamente pela "voz" do narrador, surge, na última linha, a primeira fala do interlocutor (a amante, o leitor): “- Nunca pensaste que eu poderia ser também a Morte, a tua Morte?" (OTM, p. 137). A fala da mulher ao final da narrativa representa o momento em que o leitor "transforma-se em sujeito, torna-se capaz de acção. Tendo aprendido com a história recebida, o narratário torna-se dono da palavra e mata o narrador" (DUARTE, 1984, p. 38). Matar o narrador significa liquidar a figura do narrador prepotente e que tudo sabe, tão presente na literatura neo-realista. O leitor, estando no mesmo nível do autor, também tem condições de operar na estrutura da narrativa. Sendo assim, narrador, leitor e personagem se fundem e interagem dentro da obra, subvertendo os esquemas do romance tradicional. Como considera Tutikian,

vale dizer, em outras palavras, que somada ao experimentalismo crescente empreendido no decorrer da obra de Augusto Abelaira, encontra-se a proposição de um novo público leitor, um público agora considerado como consciência ativa sempre pronta a ser chamada para participar do fazer literário. (1977, p. 10)

O triunfo da Morte, portanto, é uma obra múltipla e metaliterária. Entretanto, o ato de "ficcionalizar a ficção" não é gratuito. Ao questionar a obra e seus elementos, Abelaira acaba por apresentar o seu processo de criação próprio, os pontos norteadores do seu fazer literário. Tomando por base os aspectos metaficcionais aqui abordados, pode-se encetar uma releitura das obras do autor, atribuindo caráter de "manifesto abelairiano" a O triunfo da Morte.

A primeira característica da escrita que verificamos na obra e discutimos no presente ensaio é a questão do fingimento, da aplicação dos blefes do pôquer à arte, requerendo a argúcia do leitor. Essa criação "enganadora" e perturbadora é recorrente nas produções do autor (recuos e avanços temporais sem aviso prévio desnorteiam a linearidade da narrativa em As boas intenções, por exemplo).

O paralelo entre escrita e pôquer leva à segunda característica aqui analisada: a consideração da arte como jogo, fruto de cálculo e na dependência de parceiros. Quanto ao cálculo e construção da obra, vemos que Abelaira refuta a visão do ato criador como fruto de inspiração e, em conseqüência, nega a concepção tradicional de artista como ente superior, agraciado com um dom que o eleva sobre os demais. Escrita é trabalho, e esse aspecto é percebido na produção abelairiana, em que a pesquisa formal é intensa, caracterizada desde os primeiros romances pelo experimentalismo. A questão do jogo 
conduz à mudança de visão acerca do leitor. Ao dar voz e vez ao leitor em seu romance, Abelaira mostra que "o essencial de uma obra artística é ela ser comunicativa, ou, para ser mais preciso, é ela desencadear no seu leitor, espectador, ouvinte, etc., um processo que é também activo e criador" (SARAIVA, 1973, p. 167). Também esse elemento aparece nos outros romances abelairianos, em que o leitor é instado a montar o quebracabeça da narrativa, saindo da postura tradicional de recepção passiva. $O$ experimentalismo e os blefes narrativos das produções do autor têm como objetivo desacomodar o público, obrigando-o a agir. Em Enseada Amena, de 1966, já se denota essa preocupação: "[...] penso que se devem criar dificuldades, obstáculos à leitura, para que o leitor vença certas resistências e leia com espírito muito alerta e não passivamente" (ABELAIRA apud TUTIKIAN, 1977, p. 12). Em romances que se apresentam como construção e jogo, o leitor é parte essencial.

Sendo assim, valendo-nos da multiplicidade de $O$ triunfo da Morte, exploramos a metaficção, aspecto de fundo desse romance-sinfonia. A partir dessa leitura, podemos repensar não só a criação literária em geral, mas também a do próprio romancista, Augusto Abelaira. Romance-enciclopédia universal, romance-enciclopédia do autor.

\section{REFERÊNCIAS}

ABELAIRA, Augusto. A cidade das flores. Amadora: Bertrand, 1972. . As boas intenções. Amadora: Bertrand, 1971. . Bolor. Amadora: Bertrand, 1960. . Deste modo ou daquele. Lisboa: O Jornal, 1990. . O triunfo da Morte. Lisboa: Sá da Costa, 1981. Quatro paredes nuas. Amadora: Bertrand, 1972.

AZEVEDO FILHO, Leodegário A. de. Literatura portuguesa: história e emergência do novo. Rio de Janeiro: Tempo Brasileiro, 1987.

CALVINO, Italo. Seis propostas para o próximo milênio. São Paulo: Companhia das Letras, 2005.

CHALHUB, Samira. A metalinguagem. São Paulo: Ática, 2002.

CORTÁZAR, Julio. Obra crítica: Volume 1. Rio de Janeiro: Civilização Brasileira, 1998.

DUARTE, Lélia Parreira. O triunfo da Morte, novo caminho para o Neo-Realismo. Colóquio: Letras, Lisboa, no 81, p. 34-39, set. 1984.

GOMES, Álvaro Cardoso. O romance português contemporâneo. In: A voz itinerante. São Paulo: EDUSP, 1993. p. 83-124

JAKOBSON, Roman. Lingüística e poética. In: __. Lingüística e comunicação. São Paulo: Cultrix, 1969. p. 118-162

JÚDICE, Nuno. Dos anos 70 à década de 90. In: _. Viagem por um século de literatura portuguesa. Lisboa: Relógio D’água, 1997. p. 89-105

MOISÉS, Massaud. Dicionário de termos literários. São Paulo: Cultrix, 1992.

POE, Edgar Allan. Filosofia da composição. Disponível na Internet em:

http://www.geocities.com/SoHo/Den/9103/textolb.html - Acesso em: 24 out. 2005.

REMÉDIOS, Maria Luiza Ritzel. O romance português contemporâneo. Santa Maria: UFSM, 1986. 
SANTILLI, Maria Aparecida. A renovação do discurso na literatura portuguesa da atualidade: o texto infinito. In: Anais do XIV Encontro de Professores Universitários Brasileiros de Literatura Portuguesa. Porto Alegre: Edipucrs, 1994. p. 21-38

SARAIVA, António José. Ser ou não ser arte. Lisboa: Europa-América, 1973.

TUTIKIAN, Jane Fraga. Augusto Abelaira: uma literatura de denúncia. Porto Alegre, 1977. Dissertação (Mestrado em Literatura Portuguesa) - Instituto de Letras, Universidade Federal do Rio Grande do Sul.

ZILBERMAN, Regina. Paralelas que se encontram em algum lugar da teoria. In: Estética da recepção e história da literatura. São Paulo: Ática, 1989. p. 13-28 